\title{
Impacts of climate changes on risk zoning for cowpea in the Amazonian tropical conditions
}

\author{
João Vitor de Nóvoa Pinto ${ }^{1}$ (D), Denis de Pinho Sousa ${ }^{1}$ (D), Hildo Giuseppe Garcia Caldas Nunes ${ }^{1}$ (D), \\ Everaldo Barreiros de Souza ${ }^{2}$ (D), José Paulo de Melo-Abreu ${ }^{3}$ (D), Adriano Marlisom Leão Sousa ${ }^{1}$ (D), \\ Paulo Jorge de Oliveira Ponte de Souza ${ }^{1, \star}$ (ID \\ 1. Universidade Federal Rural da Amazônia - Instituto Socioambiental e dos Recursos Hídricos - Laboratório de Agrometeorologia - Belém \\ (PA), Brazil. \\ 2. Universidade Federal do Pará - Faculdade de Meteorologia - Programa de Pós-Graduação em Ciências Ambientais - Belém (PA), Brazil. \\ 3. Universidade Técnica de Lisboa - Instituto Superior de Agronomia - Centro de Pesquisa em Paisagem, Meio Ambiente, Agricultura e \\ Alimentos - Lisboa, Portugal. \\ Received: Apr. 10, 2021 | Accepted: Sep. 13, 2021 \\ Section Editor: Gabriel Constantino Blain \\ *Corresponding author: paulo.jorge@ufra.edu.br \\ How to cite: Nóvoa Pinto, J.V., Sousa, D. P., Nunes, H. G. G. C., Souza, E. B., Melo-Abreu, J. P., Sousa, A. M. L. and Souza, P. J. O. P. \\ (2021). Impacts of climate changes on risk zoning for cowpea in the Amazonian tropical conditions. Bragantia, 80, e5521. https://doi. \\ org/10.1590/1678-4499.20210118
}

\begin{abstract}
The climate risk zoning was carried out for cowpea cultivated in northeastern Amazonia, Pará state, Brazil. Système d’Analyse Régionale des Risques Agroclimatologiques (SARRA) crop model was used and calibrated from data obtained in field experiments conducted between 2013 and 2016 in Castanhal, state of Pará. Low climate risk areas were defined as those with water requirement satisfaction index (WRSI) greater than or equal to 0.5 during flowering and early grain development and less than $20 \mathrm{~mm}$ of total rainfall during grain maturation and harvest for at least $80 \%$ of the simulated sowings of the crop. Simulations of the current and future climate conditions were carried out with the regional climate modelling system version 4 (RegCM4) nested with the HadGEM2 global circulation model with RCP 4.5 IPCC-AR4 scenario. The results show that climate changes are likely to reduce the duration of the optimal period for sowing cowpea in the mentioned region.
\end{abstract}

Key words: Vigna unguiculata, water requirement satisfaction index, crop model.

\section{INTRODUCTION}

Rapidly increasing world population together with changes in global climate have raised questions about food security in the upcoming decades (Molotoks et al. 2021), once climate changes are expected to act in different ways across the world (Pokhrel et al. 2021). In South America, projections with the RCP 8.5 Eta-HadGEM2-ES model show a significant reduction of rainfall from the north to the south-central region of Brazil and an increased rainfall in the extreme of South America and northwestern Amazonia during rainy season (Rocha et al. 2019). Simulations carried out in a regional scale with the RegCM4 model show a reduction in rainfall during the driest months, and an increase during the wettest months in some regions of eastern Amazon (Souza et al. 2016).

In Brazil, many crops will be impacted by those changes (Zilli et al. 2020). For example, the grain yield of soybean in double crop systems in the main grain producing regions of the country is expected to drop due to decreased precipitation (Pires et al. 2016), and the northeast region of Brazil may experience reductions in sugarcane yield (Carvalho et al. 2015).

Cowpea (Vigna unguiculata Walp.), an annual herbaceous legume, is one of the crops possibly threatened by climate changes (Cavalcante Junior et al. 2016), even though its use has been proved to be a feasible strategy to guarantee food security in situations of climate change (Kimiti 2019). Researchers have found that cowpea has been used in crop rotations due to 
its ability to perform biological nitrogen fixation, and is reported to improve soil conditions and to reduce the dependency of mineral fertilizers for subsequent crops in the rotation (Sánchez-Navarro et al. 2019).

According to Companhia Nacional de Abastecimento (2021), most of Brazilian cowpea is produced in the northeast region (60.5\%), and north region (8.5\%) of Brazil. The state of Pará is responsible for 30\%, or about 17,500 tons of the production of the north region. Even though it is not a great fraction of the country's total production of cowpea, the grain has a significant economic and social role for smallholders in northeastern Pará, region the concentrates most of the state production.

Cowpea is often referred to as a drought resistant species; however, Nascimento et al. (2011) have pointed out that, even though cowpea can reach physiological maturity under drought stress, grain yield is severely reduced in such conditions. Drought, as well as deficit irrigation, can reduce biomass accumulation, grain yield, and water use efficiency (Freitas et al. 2017; Souza et al. 2019). Among various cultivated species, legumes and tuberous are the most susceptible to yield losses caused by drought, which could be explained by their shallower root systems (Daryanto et al. 2017).

Climate changes may cause severe impacts for cowpea cultivation in Brazil, such as in northeastern Brazil, where increased temperature could cause significant reductions in the area that has climate conditions favorable to cowpea growth (Silva et al. 2010). Decreases in evapotranspiration and in the duration of the crop cycle for rainfed cowpea are also expected in different warming scenarios (Cavalcante Junior et al. 2016). Angelotti et al. (2020) found in a controlled growth chamber that some cowpea cultivars show higher dry matter production and number/weight of seeds under elevated $\mathrm{CO}_{2}$ concentration $(500 \mathrm{ppm})$. Besides yield increase of the plants, elevated $\mathrm{CO}_{2}$ concentration improves plant water relations by reducing its stomatal conductance (Hatfield and Dold 2019) as observed for rice (Kumar et al. 2019) and mung bean (Gao et al. 2015). Despite there are no results found for cowpea, it is expected a similar response for some C3 plants (Hatfield and Dold 2019).

Water deficits higher than $47 \mathrm{~mm}$ during reproductive stage promote larger yield gaps on cowpea cultivated in northeastern Pará state, which defines an optimal sowing season for the cultivar BRS-Tracuateua up to June 20th as the limit optimal sowing date in order to avoid yield gaps higher than $20 \%$ (Souza et al. 2020). The ideal final sowing date for cowpea in this region in order to guarantee the highest yield ( $90 \%$ of probability) and yield gaps less than $10 \%$ would be between April 1st to 20th (Nunes et al. 2019).

The aim of this study is to estimate possible impacts of regional climate changes on the duration of the optimal growing season and on the amount of area available for growing cowpea in the northeast of Pará (Eastern Amazon), Brazil. The results are discussed and possible strategies that farmers may recur to in order to minimize economic and social impacts are pointed. The hypothesis is that climate changes may alter the optimal sowing period for cowpea in the studied region.

\section{MATERIAL AND METHODS}

Field experiments were carried out in the School Farm of the Federal Rural University of Amazon, in Castanhal, PA $\left(1^{\circ} 19^{\prime} 14.7^{\prime \prime}\right.$ S; 47 $\left.57^{\prime} 33.5^{\prime \prime} \mathrm{W}\right)$ during the years of 2013, 2014, 2015, and 2016. These experiments allowed the acquisition of the data necessary to perform the calibration and validation of the Système d'Analyse Régionale des Risques Agroclimatologiques version $H$ (SARRA-H) model. In such experiments, cowpea was grown with different irrigation depths, with 0.5 and $0.1 \mathrm{~m}$ of spacing between each plant, therefore totalizing $2 \times 10^{5}$ plants.ha $^{-1}$.

The daily water supply through irrigation was based on crop evapotranspiration (ETc) calculated according to Allen et al. (1998), with the crop coefficients (Kc) recommended by Farias et al. (2017). Reference evapotranspiration was calculated with weather data recorded in an automated weather station located $3 \mathrm{~km}$ away from the experiment. Sensors were installed in the experiment to measure the following variables: air and soil temperature $\left({ }^{\circ} \mathrm{C}\right)$, relative humidity of air $(\%)$, soil moisture $\left(\mathrm{m}^{3} \cdot \mathrm{m}^{-3}\right)$, global radiation $\left(\mathrm{W} \cdot \mathrm{m}^{-2}\right)$, net radiation $\left(\mathrm{W} \cdot \mathrm{m}^{-2}\right)$, soil heat flux $\left(\mathrm{W} \cdot \mathrm{m}^{-2}\right)$, rainfall $(\mathrm{mm})$, wind speed $\left(\mathrm{m} \cdot \mathrm{s}^{-1}\right)$ and direction measured at $2 \mathrm{~m}$ height.

The field experiment was carried out in randomized blocks design, with six blocks and four treatments (L1, L2, L3, and L4). In L1, 100\% of the ETc was supplied every day through irrigation, while in L2, L3 and L4, the percentage reduces to 
50, 25 and $0 \%$ (no irrigation), respectively. All treatments received the same amount of water from irrigation until the end of the vegetative phase of the crop.

Every week during the crop growth period, three plants were taken from each parcel for determination of shoots dry mass. Three discs with a diameter of $2 \mathrm{~cm}$ each were taken from each plant for the determination of the specific leaf area, and subsequent calculation of leaf area index.

\section{Description of the SARRA crop model}

The SARRA model integrates three processes: water balance, carbon balance, and crop phenological development. The details on the calculations performed are described by Cirad (2013). The model calculates the reference evapotranspiration each day based on the weather records, according to the methodology proposed by Allen et al. (1998). The model inputs the following weather data for each day: maximum and minimum air temperature, average actual vapor pressure obtained from air temperature and air relative humidity, precipitation, global radiation, and wind speed measured at $2 \mathrm{~m}$ height from the surface. Despite some cowpea cultivars shown higher dry matter production and number/weight of seeds under elevated $\mathrm{CO}_{2}(500 \mathrm{ppm}$ ) in a controlled growth chamber (Angelotti et al. 2020), no penalization was applied in the processes of the model due to $\mathrm{CO}_{2}$ increment once the objective was only to simulate the crop water consumption in order to generate the water requirement satisfaction index of cowpea.

\section{Assessing the performance of the SARRA model}

The crop parameters needed as input for the model were obtained from the experiments of 2013, 2014, and 2015, then the weather data from 2016 was supplied as input for the model and a simulation was carried out. The model output was compared to the measured data by means of the Pearson's correlation coefficient (r), Willmott's index of agreement (d), performance index $(c)$, mean error and root of mean square errors (me).

\section{Water requirement satisfaction index}

The water requirement satisfaction index (WRSI) is the ratio of actual to maximum evapotranspiration. The WRSI ranges from 0 to 1 . Its critical values depend on the crop and its phenological phase. For cowpea, WRSI $\geq 0.5$ can be considered as low water deficit (Silva et al. 2010).

Although it is expected greater stomatal control and possible reduction in the transpiration of C3 plants (Hatfield and Dold 2019), no correction has been applied to the evapotranspiration estimate, once there are no experimental results for this crop, and because it is considered that both maximum evapotranspiration and actual evapotranspiration would be affected, which could cause little impact on the WRSI compared to the difference between them.

\section{Simulation of sowing for different dates}

Simulations of the current and future climate conditions were carried out with the regional climate modelling system version 4 (RegCM4) nested with the HadGEM2 global circulation model with RCP 4.5 IPCC-AR4 scenario, considering an intermediate scenario in terms of the global radiative forcing of approximately $4.5 \mathrm{~W} \cdot \mathrm{m}^{2}\left(\sim 650 \mathrm{ppm} \mathrm{CO}_{2}\right.$ equivalent $)$ for future climate conditions (Souza et al. 2016). The simulations were performed for 22 locations in northeastern Pará state and western Maranhão state (Fig. 1) and, for each location, the output of the model was compared with records of a corresponding weather station in order to obtain correction factors for correction of the model bias, both under current and future climate simulations.

For air temperature and air relative humidity, additive biases were calculated, and for global radiation, precipitation and wind speed, multiplicative biases were used (Souza et al. 2016). The correction factors were calculated for each location and month. 

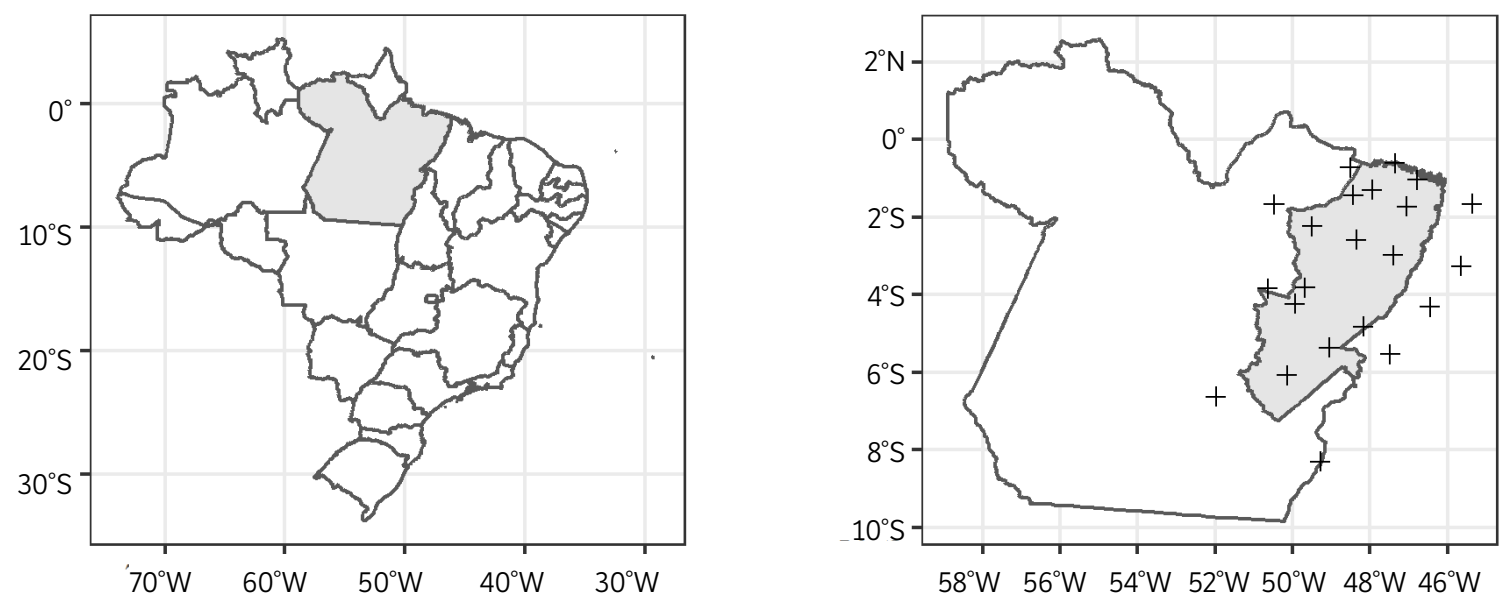

Figure 1. Location of the studied area. Each cross represents a weather station.

The predominant soil texture in each location was determined from the map of soils of the states of Pará and Maranhão. Water holding capacities of $80,120,150,180$, and $150 \mathrm{~mm} \cdot \mathrm{m}^{-1}$ were used for the following soil textures, respectively: sandy, sandy loam, loam, clay loam, clay.

The sowing of cowpea was simulated in each location in the 5th, 15th, and 25th days of each month and year, from 2006-2016, 2016-2026 and 2026-2036. The average WRSI from the flowering until the end of grain filling was calculated for each simulation. Then, an inverse distance weighting interpolation of the probability ( $\mathrm{pW}$ ) of occurrence of an average WRSI greater than the threshold value mentioned above was performed. Also, for each sowing date, the probability $(\mathrm{pR})$ of the total rainfall during the grain maturation period until harvest not exceeding a threshold value of $20 \mathrm{~mm}$ was calculated, since cowpea yield is negatively impacted by excessive rainfall during the harvest period (Lima Filho et al. 2013). Four classes of risk were defined: low risk, medium risk, high risk and not recommend; where "not recommended" means the sowing of cowpea is not recommended in that region and date. Regions defined as low risk, medium risk or high risk must meet the criteria $\mathrm{pW}>\mathrm{p}_{\min }$ and $\mathrm{pR}>\mathrm{p}_{\min }$, where $\mathrm{p}_{\min }$ is equal to 80,70 , and $60 \%$, respectively, for low risk, medium risk and high-risk zones. If such criteria are not met for a given region and sowing date, then it is classified as not recommended. These criteria are similar to the criteria adopted in the project of risk zoning of Brazil for cowpea (Andrade Júnior et al. 2018).

\section{RESULTS}

\section{Performance of the crop model}

The SARRA-H model overestimates grain yield in L1, L2, and L3, and underestimates it in L4 (Table 1). In L1, the simulated average grain yield was $1,556 \mathrm{~kg} \cdot \mathrm{ha}^{-1}$, and the measured grain yield was $1,338 \pm 284 \mathrm{~kg} \cdot \mathrm{ha}^{-1}$ (average \pm confidence interval, $\mathrm{p}=0.05$ ). It demonstrates that the simulated grain yield does not differ statistically from the measured values in this treatment.

Since the SARRA model uses the ratio of actual to potential transpiration to limit the biomass accumulation, an accurate simulation of biomass accumulation indicates that the impacts of water deficit on the crop are being correctly simulated. Thus, a correct simulation of biomass accumulation is necessary, even though this output is not being used throughout this study. The results suggest that model simulates biomass accumulation with good precision and accuracy (Table 1). 
Table 1. Pearson correlation coefficient ( $r$ ), Willmott's index of agreement (d), performance index (c), and mean error (me), for simulated dry mass of shoots $(\mathrm{S})$, leaves (L), stems (St), grains $(\mathrm{Y})$, leaf area index (LAl), and soil water content (W), during the validation of the model.

\begin{tabular}{|c|c|c|c|c|c|c|c|c|c|c|}
\hline \multirow{3}{*}{ Variable } & $r$ & d & c & $r^{2}$ & me & $r$ & d & c & $r^{2}$ & me \\
\hline & \multicolumn{10}{|c|}{ Treatment } \\
\hline & \multicolumn{5}{|c|}{ L1 } & \multicolumn{5}{|c|}{ L2 } \\
\hline$S$ & 0.99 & 0.99 & 0.98 & 0.98 & -112.11 & 0.99 & 0.99 & 0.97 & 0.98 & 209.50 \\
\hline$L$ & 0.95 & 0.96 & 0.91 & 0.90 & -169.00 & 0.98 & 0.98 & 0.95 & 0.95 & 24.37 \\
\hline St & 0.97 & 0.98 & 0.96 & 0.95 & -138.54 & 0.95 & 0.97 & 0.93 & 0.90 & 59.92 \\
\hline$Y$ & 0.93 & 0.88 & 0.82 & 0.87 & 221.76 & 0.91 & 0.90 & 0.82 & 0.83 & 141.97 \\
\hline LAI & 0.85 & 0.89 & 0.75 & 0.72 & -0.23 & 0.73 & 0.84 & 0.61 & 0.53 & -0.06 \\
\hline W & 0.97 & 0.97 & 0.94 & 0.94 & -0.56 & 0.82 & 0.87 & 0.71 & 0.67 & -2.01 \\
\hline \multirow{2}{*}{ Variable } & \multicolumn{10}{|c|}{ Treatment } \\
\hline & \multicolumn{5}{|c|}{ L3 } & \multicolumn{5}{|c|}{ L4 } \\
\hline$S$ & 0.99 & 0.99 & 0.97 & 0.98 & 209.50 & 0.98 & 0.99 & 0.97 & 0.96 & 90.87 \\
\hline$L$ & 0.98 & 0.98 & 0.95 & 0.95 & 24.37 & 0.98 & 0.94 & 0.92 & 0.96 & 130.32 \\
\hline St & 0.95 & 0.97 & 0.93 & 0.90 & 59.92 & 0.97 & 0.99 & 0.96 & 0.95 & -6.39 \\
\hline$Y$ & 0.91 & 0.90 & 0.82 & 0.83 & 141.97 & 0.93 & 0.95 & 0.88 & 0.87 & -20.53 \\
\hline LAI & 0.73 & 0.84 & 0.61 & 0.53 & -0.06 & 0.95 & 0.89 & 0.84 & 0.90 & 0.18 \\
\hline$W$ & 0.82 & 0.87 & 0.71 & 0.67 & -2.01 & 0.96 & 0.98 & 0.95 & 0.93 & 0.51 \\
\hline
\end{tabular}

\section{Predicted changes in climate}

The average air temperature during the decade $2006-2016$ ranges between 24.00 and $27.80^{\circ} \mathrm{C}$, depending on the location. Simulations carried out with the RegCM4 model show a consistent average increase of $0.33{ }^{\circ} \mathrm{C}$ (ranging from 0.25 to $0.41^{\circ} \mathrm{C}$ ) in temperature throughout the simulated decade 2016-2026 and 2026-2036 for all locations (Fig. 2), with positive anomalies compared to decade 2006-2016 in most of the regions of study.

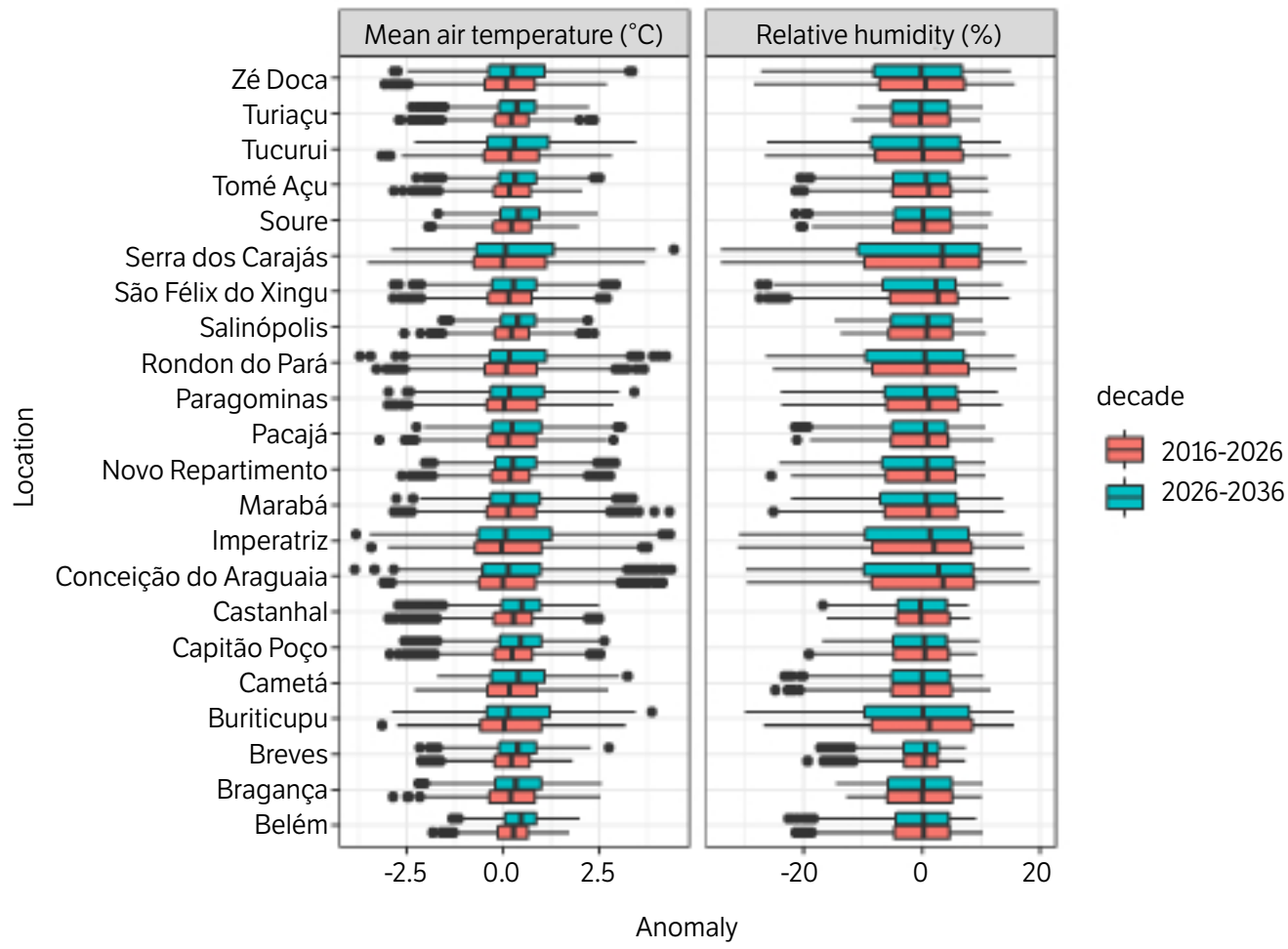

Figure 2. Anomalies of relative humidity $(\mathrm{RH})$ and daily mean air temperature $(\mathrm{T})$ throughout the decades with the mean air temperature and relative humidity of 2006-2016 decade taken as a baseline. The black line represents the mean over the region, and the gray area shows the maximum and minimum of the daily mean registered over the region on each date from 2006 to 2036 . 
Simulations also show a noticeable increase in air temperature throughout the decades, with more positive anomalies in the decade 2026-2036 in almost all cities studied, except those located in the southeast of the region and within the state of Maranhão, where it is observed some minor negative anomalies over the year.

It is observed positive anomalies in air temperature by about $1.0^{\circ} \mathrm{C}$ based on 1st quartile until 2036, reaching positive anomalies close to $2.5^{\circ} \mathrm{C}$ considering the 3 rd quartile. Such an increase in temperature could reduce the time needed to harvest annual crops that reach physiological maturity earlier when growing under higher temperatures. These effects of temperature on the crop are well simulated by SARRA-H.

Mean air relative humidity ranges from 70 to $84 \%$ over the studied region during the first decade (2006-2016). Unlike air temperature, relative air humidity does not show a clear trend, since some places are likely to experiment some increase in relative air humidity, while others will experiment decreases, and yet some locations will have no noticeable changes (Fig. 2). It is noteworthy that relative humidity is expected to decrease in most continental areas during warming scenarios, however, decreases in relative humidity in continental areas may be linked to lower water supply from evapotranspiration (Vicente-Serrano et al. 2018). The simulated data show a noticeable downtrend in relative humidity only during the last few years of the simulated data (between 2026-2036), as shown in Fig. 2.

Global radiation and wind speed have shown no meaningful changes throughout the decades (Fig. 3). The period with the higher global radiation occurs during the second half of the year, when the average daily global radiation ranges from 16.9 to $23.0 \mathrm{MJ} \cdot \mathrm{m}^{-2}$. day ${ }^{-1}$. The lower global radiation occurs during the first half of the year, which are the wetter months. The average global radiation during the rainy season ranges from 13.3 to $18.1 \mathrm{MJ} \cdot \mathrm{m}^{-2} \cdot \mathrm{day}^{-1}$ and depends upon the location.

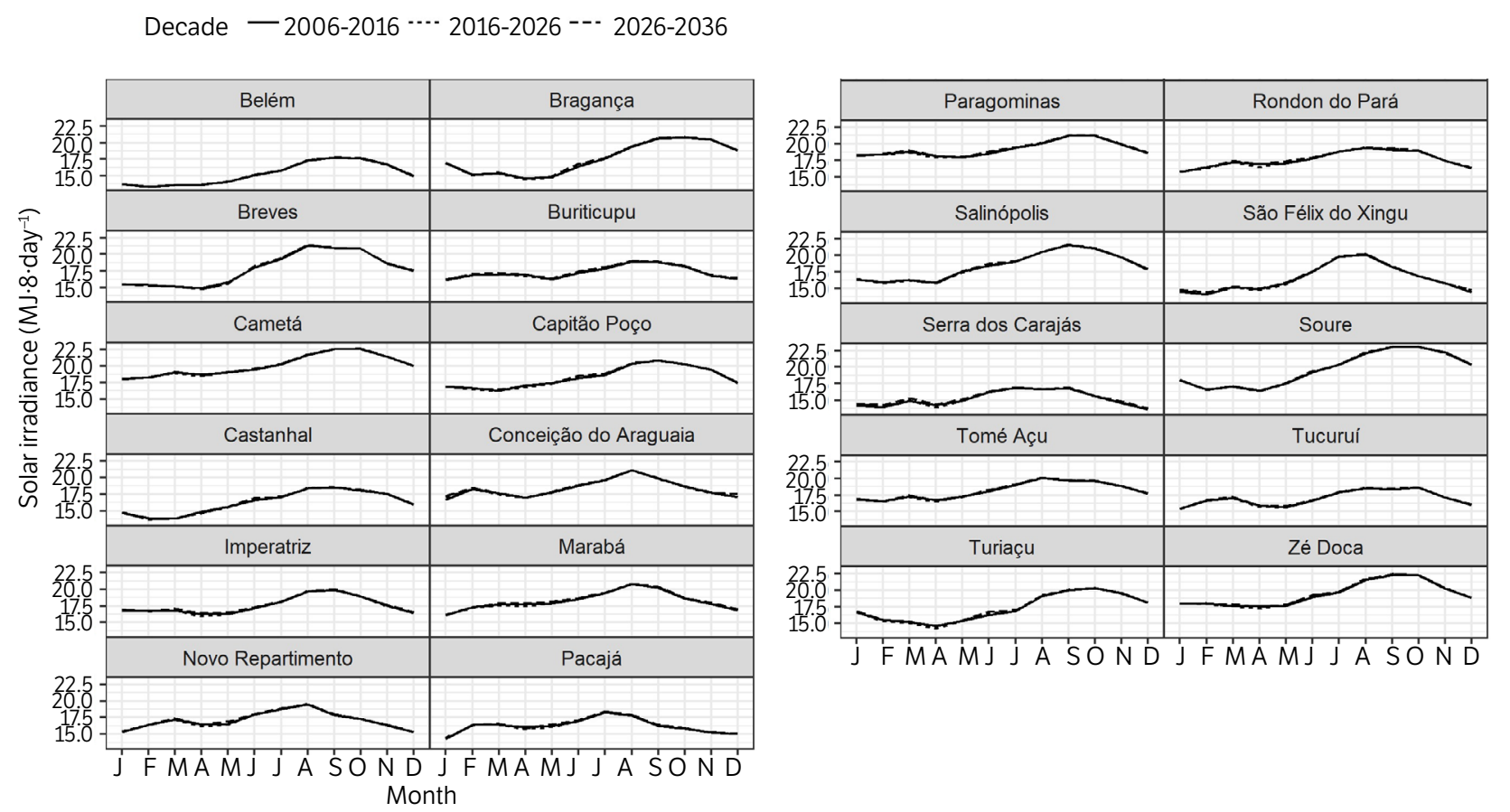

Figure 3. Average daily global radiation for each month and location in the three simulated decades.

Wind speed is not expected to have meaningful variations in the upcoming decades (data not shown). Solaun and Cerdá (2020) have shown an increase in wind speed near surface during warming scenarios occurring in other countries, but these studies usually simulate wind speed at $10 \mathrm{~m}$ height or higher and have larger timeframes. Rainfall is expected to increase during the wet season and to decrease during the dry season in most locations in northeastern Pará, in the coming decades. Such changes in rainfall patterns are well described and discussed in Souza et al. (2016). 


\section{Climate risk zoning under recent past}

The decade from 2006 to 2016 was included in this analysis to represent climate conditions in the recent past (Fig. 4) for comparison purposes. The ideal sowing period begins in early March for the central region of the studied area. However, the climate risk at the beginning of March is still high due to a high probability of rainfall during harvest. The area available for sowing increases from $1.8 \%$ of the total studied area to $54.6 \%$ of the total studied area from between February 15 and March 25. All the regions suitable for sowing from May 15 onwards are north of the parallel $2^{\circ} \mathrm{S}$, and they stay as such until June 25 . The ideal period for sowing begins earlier in the southernmost regions of the studied area and advances northward.

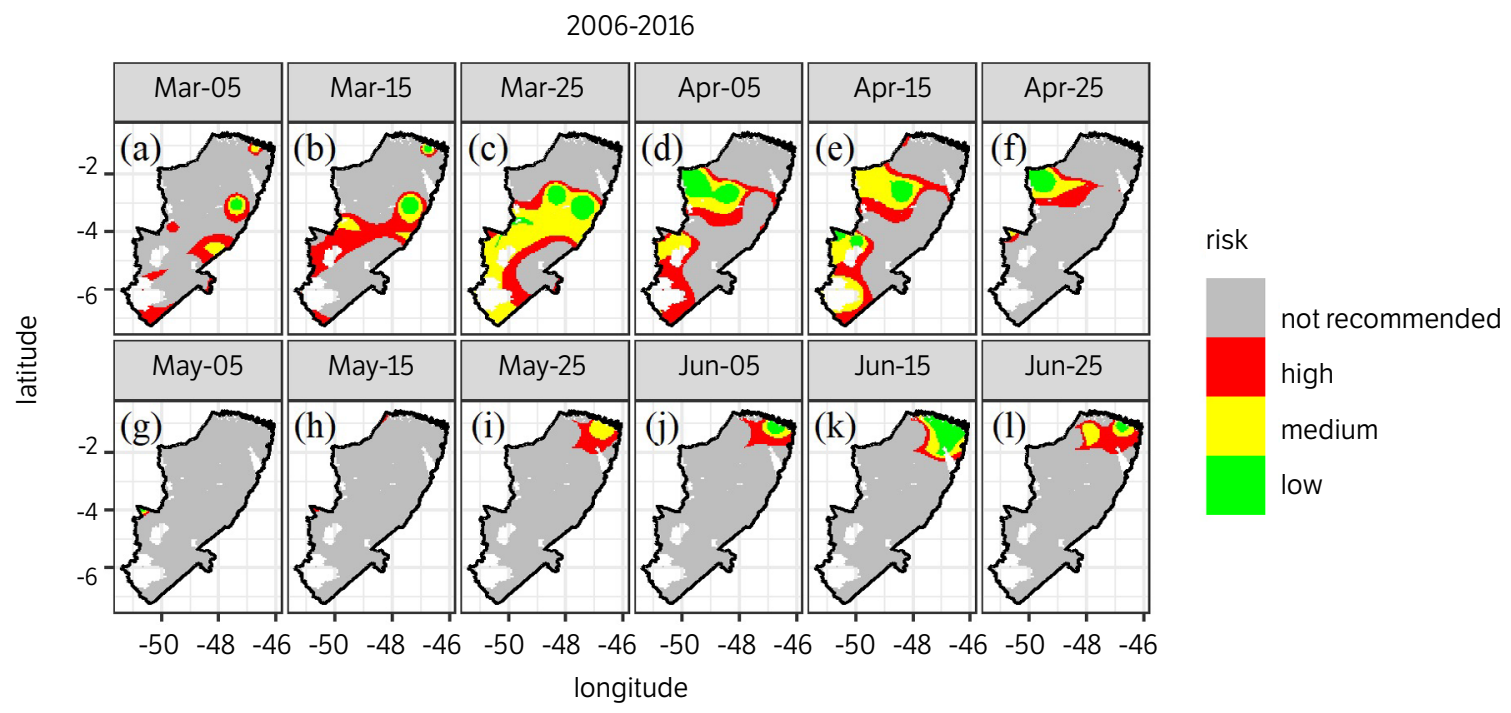

Figure 4. Climate risk zoning for cowpea throughout the 2006-2016 decade.

The increase of the climate risk during the second half of the year in the whole region is due to diminished amounts of rainfall, caused by the displacement of the intertropical convergence zone (ITCZ). The ITCZ is the main rain generating system in the eastern Amazon, more precisely in Maranhão and northeastern Pará, during the wet season (Ferreira et al. 2015; Souza et al. 2017). The annual seasonality of rainfall is strongly related to the displacement of ITCZ, which occurs along the NW-SE axis, leading to increased precipitation in Amazon in the first quarter of the year and in Central America in the third quarter of the year (Rocha et al. 2019). Despite the effect of the displacement of the ITCZ, the rain distribution observed during the dry regime during the second half of the year is mainly controlled by other meteorological systems, such as convective complexes, instability lines and influences of frontal bands located in the Brazilian northeast (Souza et al. 2017).

\section{Climate risk zoning under current and future conditions}

Throughout the decade 2016-2026 (Fig. 5), a decrease of the climate risk in most regions between March 25 and April 15 was observed. The zone available for the sowing of cowpea expands from 5.7 to $25.0 \%$ of the studied region between February and March, until it reaches $67.2 \%$ of the total available area on April 5. Then, it falls to $0 \%$ after May 5, when the ideal period for sowing end for regions south of the parallel $2^{\circ} \mathrm{S}$. Still, all the regions suitable for sowing from May 25 onwards are north of the parallel $2^{\circ} \mathrm{S}$, and they stay as such until June 5 . 


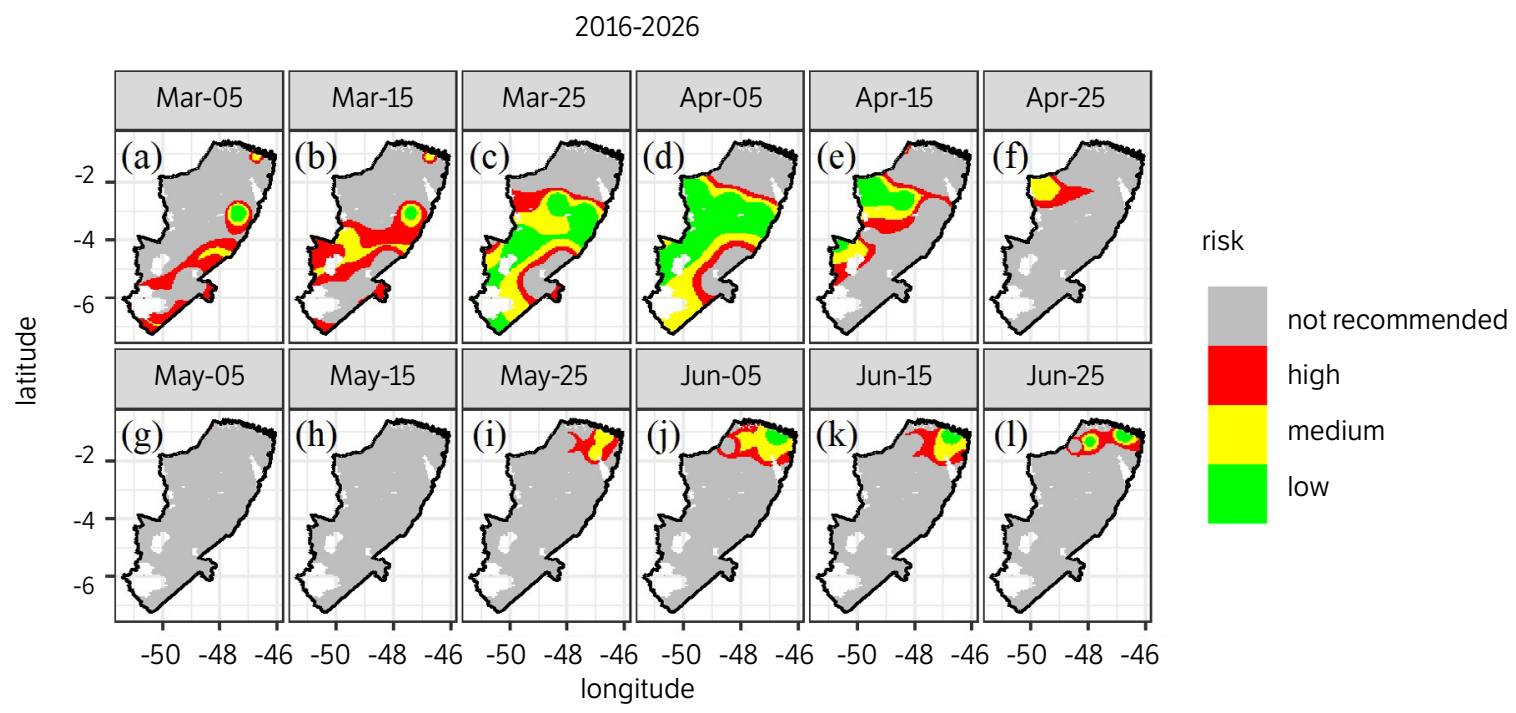

Figure 5. Climate risk for each sowing date throughout the 2006-2016 decade.

Throughout the decade 2026-2036 (Fig. 6), the onset of ideal period for sowing occurs at the end of February for the central regions of the studied area. The zone suitable for sowing increases from 1.0\% in February 15 to 46.9\% in March 25. All the regions suitable for sowing from May 5 onwards are north of the parallel $2^{\circ} \mathrm{S}$.

2026-2036

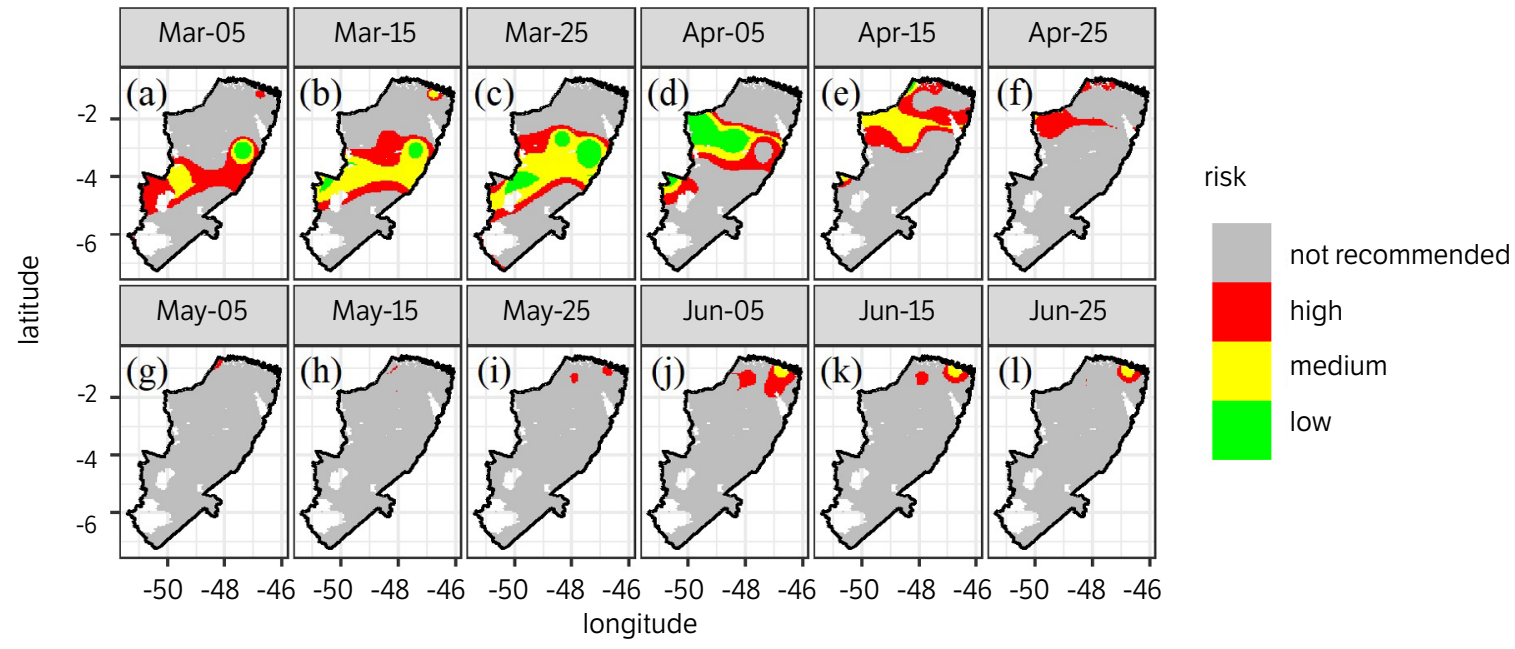

Figure 6. Climate risk for each sowing date throughout the 2026-2036 decade.

April represents the end of the growing season in most of the region, in all the three decades from 2006 to 2036, except for a small region in the northeast of the studied area. By the end of the growing season, in April, the lower risk zones move northward until only the northern coastal region remains as a low-risk zone. This pattern is maintained throughout all three decades. The coastal region, in the north, remains suitable for sowing until the end of June during the three simulated decades.

The WRSI-related component of the climate risk, which characterizes the risk of water deficit, decreases significantly during November (Fig. 7c, f, i); however, the duration from sowing to harvest of cowpea is smaller than the duration of the rainy season, so an early sowing during November until February is likely to face large amounts of rain during the harvest period (Fig. 7b, e, h). 


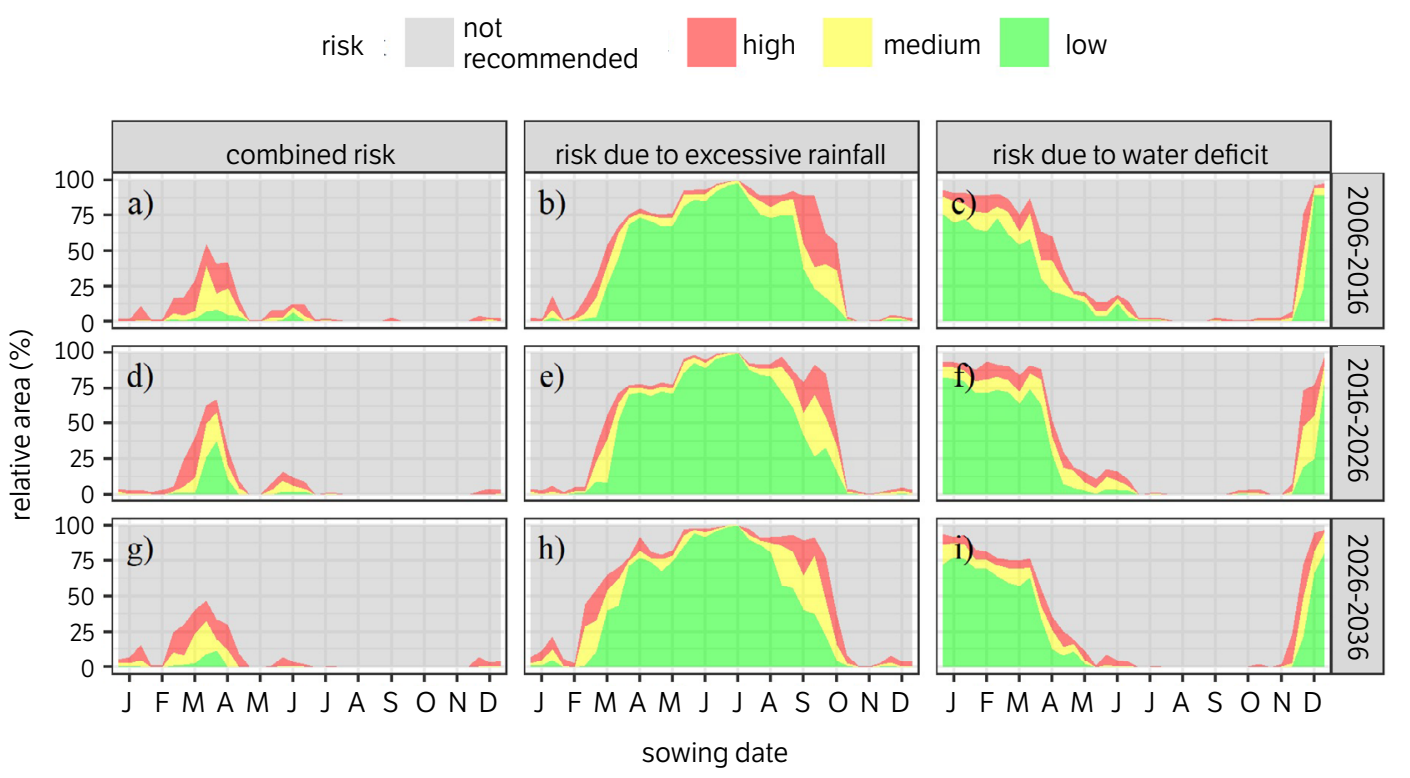

Figure 7. Stacked area plot of the percent of the total studied area in each risk classification by date of sowing.

Even though the length of the low-risk season slightly varies over decades, the expansion and the retracement of the low-risk zones follow a similar pattern, which stays unaltered over time: from March to April (Fig. 4a-f, Fig. 5a-f, Fig. 6a-f), the zones with lower risks move along the SE-NW axis. Then, from May to June (Fig. 4g-l, Fig. 5g-l, Fig. 6g-l) the ideal period for sowing moves to the northeastern coastal region. Thus, the low-risk season in the southern region begins and ends earlier than in the northern region.

\section{Impacts of climate change on climatic risk zoning}

Simulations show a continuous shortening of the low-risk period over decades for the northeastern region of the studied area. Such a shortening occurs due to the increase of risk in May and June (Fig. $8 \mathrm{~g}-\mathrm{l}$ and Fig. $9 \mathrm{~g}-\mathrm{l}$ ). It is important to highlight that this region concentrates a significant amount of the total cowpea yield of the state.

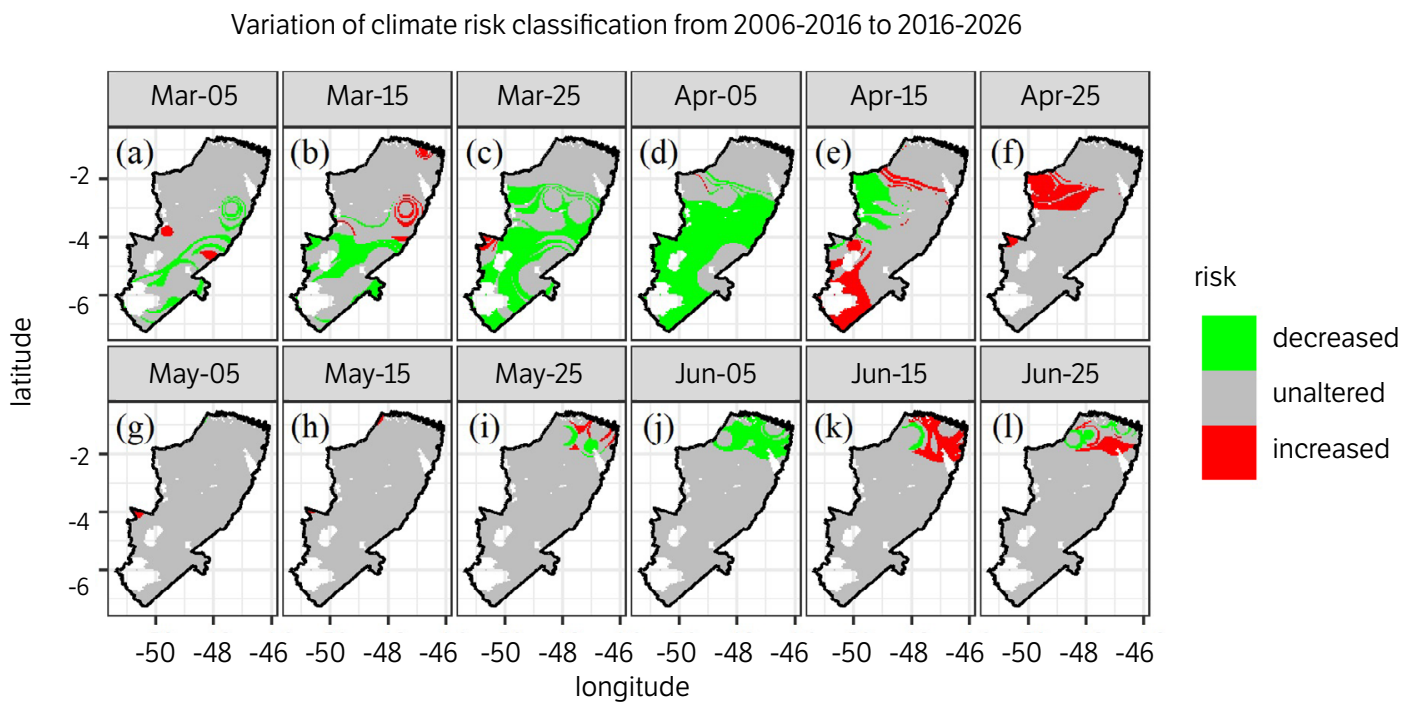

Figure 8. Reclassification of climate risk from 2006-2016 to 2016-2026. Regions where the climate risk increased are in red, whereas green pixels represent regions where the climate risk decreased. 
The 2016-2026 decade has a great increase in climate risk on April 15 and April 25 (Fig. 8e-f) and a decrease of risk from March 5 to April 15 (Fig. 8a-e). The decrease of risk was due to areas whose classification changed from medium risk to low risk or from high risk to medium risk. Such a decrease in risk seems to be driven by increased rainfall during the early development of the crop (compare Fig. $7 \mathrm{c}$ and $\mathrm{f}$ between March and April). However, the decrease of climate risk in March and April is counterbalanced by an increase of risk in June.

On the other hand, the period from March 15 to April 15 (Fig. 9h-k) in the decade 2026-2036 shows up to 50,000 km² of reclassified areas, most of which were previously classified as low-risk or medium-risk zones and were reclassified as high-risk zones or "not recommended" for sowing. Such an increase in climate risk at the beginning of the growing season may be due to changes in rainfall distribution over the year, since the risk due to water deficit during grain maturation and harvest increases in April (Fig. 7c, f, i) in comparison to the previous decades. The future decades (2016-2026 and 20262036) have an increase in rainfall of about 5 to $10 \%$ in the wettest months (December-February), and a reduction in rainfall of -5 to $-30 \%$ during the driest months (June-August) (Souza et al. 2016).

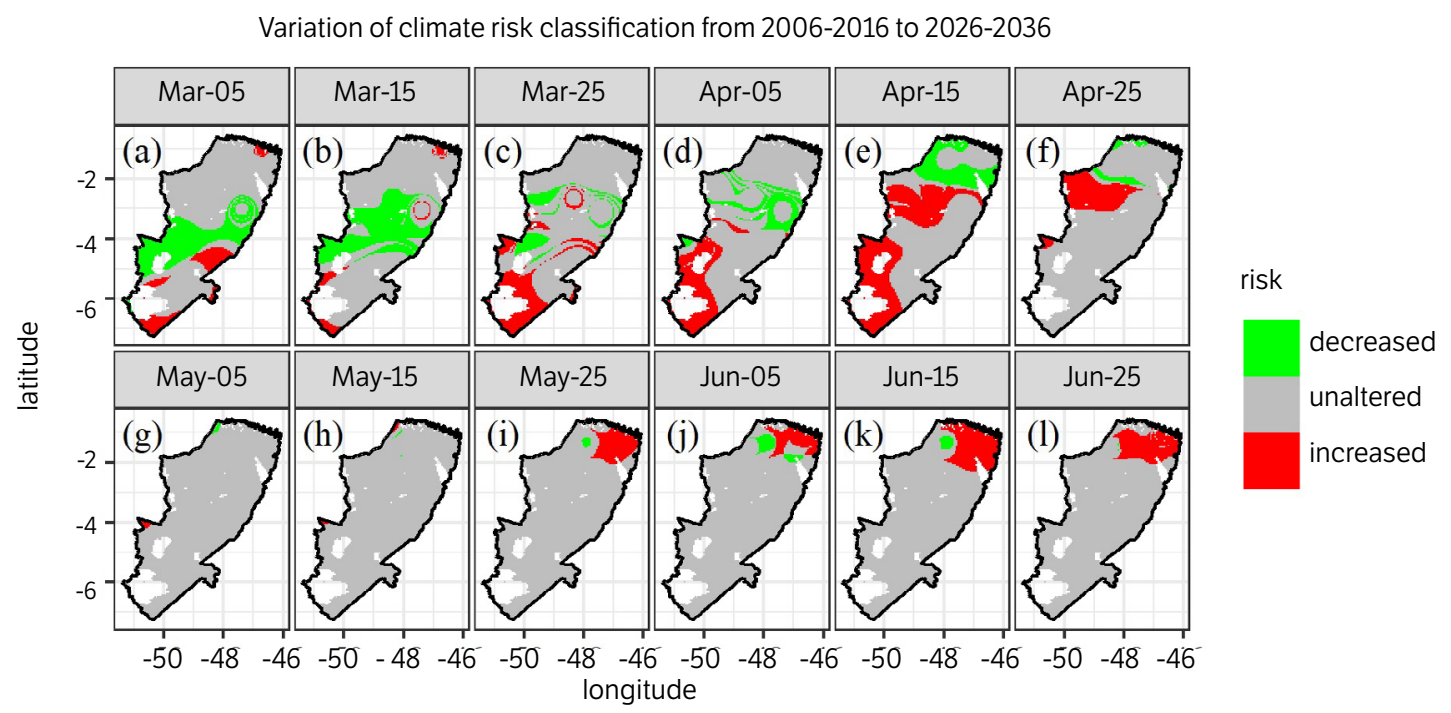

Figure 9. Reclassification of climate risk from 2006-2016 to 2026-2036. Areas where the climate risk increased are in red, whereas green pixels represent regions where the climate risk decreased.

\section{DISCUSSION}

In northern Brazil, cowpea is typically grown during the third growing season, which begins in May and ends in midJuly (Auras and Amâncio 2015). The highest yields of cowpea for the northeast region of Pará are obtained when it is sown between April 1st to 20th (Nunes et al. 2019). After May 20th, yield gaps of more than $20 \%$ are expected due to the climatological water deficit in the region during reproductive stage of this culture (Souza et al. 2020). In similar studies carried out for different regions of Brazil, water deficit seems to be the main limiting factor for cowpea production. Andrade Júnior et al. (2007), based solely on the WRSI criteria, found the period from December 15 to March 25 to be the optimal period to sow cowpea in the state of Ceará, northeast of Brazil. Lima Filho et al. (2013) defined the period from mid-June to mid-July in Cruz das Almas, northeast of Brazil.

The annual precipitation in all these places is much lower than the annual precipitation in northeastern Pará. The annual precipitation in Cruz das Almas is 1,117 mm.year ${ }^{-1}$ (Lima Filho et al. 2013), in the state of Ceará, records of annual precipitation reach 1,669 $\mathrm{mm}$ in Fortaleza and $1,668 \mathrm{~mm}$ in Guaramiranga (Andrade Júnior et al. 2007). While in northern Pará, annual precipitation records are: 2,510 mm.year ${ }^{-1}$ in Tracuateua, 3,084 mm.year-1 in Belém, and 1,899 mm.year-1 
in Marabá (this study). If a rainfall constraint was not taken into consideration, the low-risk period in this study would be much longer: from December to July.

Changes in rainfall patterns may have implications for farmers who choose to sow at the beginning of the low-risk period, since the wetter condition during the crop harvest may causes losses due to the spreading of inocula from infected plants to healthy ones through water droplets and water flow on the surface of the soil (Durojaye et al. 2019). Moreover, cowpea sown too early will be harvested during the rainiest months, which usually causes more damages to the physical structure of the soil due to the combination of high soil moisture and the traffic of heavy machinery (Gabarron-Galeote et al. 2019).

The observed increase of climate risk for regions north of parallel $2^{\circ} \mathrm{S}$ throughout the current (2016-2026) and future (2026-2036) decades for cowpea suggests that farmers will need to adapt to a narrower sowing window for the studied region. A migration of cowpea production in the whole region could be seen, which could have significant impact for small farmers who have relied in cowpea as a source of food and income.

In the future, as climate changes develop, in order to have proper water supply during its vegetative development and early reproductive phase, farmers could sow earlier. Irrigation and/or the use of varieties that are more resistant to drought stress are also alternatives in case of late sown (Nascimento et al. 2011; Souza et al. 2019). Cowpea is considered conservative, which means it prioritizes water status maintenance rather than photosynthesis. Therefore, stomatal closure, which reduces evapotranspiration, is an important drought tolerance mechanism for this species (Freitas et al. 2017). However, this comes with the side effect of significant reductions in grain yield (Freitas et al. 2017; Souza et al. 2019). Any of these alternatives would, therefore, have social and/or economic costs for farmers in general, and specially for smallholders.

Higher atmospheric $\left[\mathrm{CO}_{2}\right]$ primarily affects the net photosynthesis of $\mathrm{C}_{3}$ plants by increasing net photosynthesis and carbon assimilation, which is counteracted by a reduction of stomatal opening, that reduces the transpiration of the plant (Ueyama et al., 2020). One could expect this reduction in plant transpiration to increase the crop resistance to drought, however a research about the effect of $\mathrm{CO}_{2}$ fertilization and water deficit on cucumber, another $\mathrm{C}_{3}$ plant, has shown that severe water stress would reduce or even offset the possible benefits brought by increased atmospheric $\left[\mathrm{CO}_{2}\right]$, which, according to the authors, suggests that ecological models based on strong $\mathrm{CO}_{2}$ fertilization may overestimate the benefits of plants from rising atmospheric $\left[\mathrm{CO}_{2}\right]$ (Fan et al. 2020). As there is not any recent experiment regarding the effects of increased atmospheric $\left[\mathrm{CO}_{2}\right]$ on cowpea, the current research does not account for effects of $\mathrm{CO}_{2}$ fertilization on cowpea.

Earlier sowing would reduce the amount of time available to grow other crop(s) in double cropping systems, which are widely used to intensify the use of cropland and thus increase the economic returns of farming (Pires et al. 2016). In some colder regions around the world, climate changes are likely to increase the suitability of double cropping, since a warmer climate would reduce the amount of time needed to grow crops (Seifert and Lobell 2015).

However, in the region of the current study, changes in rainfall patterns have a greater impact upon climate risk than the temperature increase (Souza et al. 2016). Although an increase of total rainfall during the rainy season is expected for this region, studies indicate a possible change of the position of the ITCZ as a consequence of climate changes. A southward shift during May-October and a shift towards the Equator between November and April (Mamalakis et al. 2021) could minimize the scenarios of high climate risk expected for the near future based solely on the results of the RegCM4 model, primarily in the dry season.

Irrigation, as mentioned, can be used to mitigate impacts on cowpea sown at the end of the low-risk season (Souza et al. 2019). The irrigation requirements are expected to increase in all Brazilian regions until 2039 (Cunha et al. 2014), however, in some regions of Amazon, deforestation and climate changes could alter water availability (Gomes et al. 2020) and drive water use to unsustainable levels in the upcoming decades (Lathuillière et al. 2018). Taxation on water use could be instrumental to increase water productivity (Berbel et al. 2019). Smallholder farmers are more susceptible to climate changes, and more likely to experience some food insecurity following extreme weather events (Harvey et al. 2018).

The decision on which date to adopt as a new sowing window must consider the new rainfall regime for the region for the upcoming decades (2016-2026 and 2026-2036), whose scenarios indicate an increase of 5 to $10 \%$ in the rainy trimester (DJF) and a 5 to $30 \%$ reduction in the dry semester (JJA) (Souza et al. 2016). Such scenarios may increase the possibility of greater yield gap for cowpea due to the higher frequency of water deficiencies during the reproductive phase, considering 
that for this region and for this crop, when water deficits during reproductive stage reach more than $47 \mathrm{~mm}$, yield gaps greater than $20 \%$ can occur (Souza et al. 2020).

In other regions, such as northeastern Brazil, cowpea will be impacted in similar ways due to climate change, where increased temperature could reduce the area with low climate risk (Silva et al. 2010). A decrease on the time the crop needs to reach physiological maturity is also expected in different warming scenarios (Cavalcante Junior et al. 2016). Even small changes in the sowing date could drastically reduce the aboveground biomass (Matoso et al. 2018), number of pods per plant and number of grains per pod, which results in lower yield (Almeida et al. 2017).

Finally, for practical purposes, the optimal sowing dates for cowpea for each decade, in chronological order, can be described as follows: for regions between $3^{\circ} \mathrm{S}$ and $5^{\circ} \mathrm{S}$ it is, respectively, March 25, from March 25 to April 5, and from March 15 to March 25. For regions north of $2^{\circ} \mathrm{S}$, it is from May 25 to June 25, from May 25 to June 25, from June 15 to June 25. For regions south of $5^{\circ} \mathrm{S}$, the sowing is not recommended in 2026-2036; in the other two decades, it is, respectively, from March 25 to April 15, and from March 25 to April 5. For better spatial precision, the raster images should be used.

\section{CONCLUSION}

Simulations show that climate changes are likely to reduce the duration of the optimal period for sowing cowpea. Such a reduction is due to limited water supply at the end of the wet season in northeastern Pará. Farmers may adapt to such changes by sowing earlier, in order to avoid the crop development occurring during the dry season, or by irrigating. However, any of these strategies would have economic and social costs for farmers.

\section{AUTHORS' CONTRIBUTION}

Conceptualization: Pinto, J. V. N., Melo-Abreu, J. P. M. and Souza, P. J. O. P.; Methodology: Souza, E. B., Sousa, A. M. L. and Souza, P. J. O. P.; Investigation: Pinto, J. V. N., Sousa, D. P. and Nunes, H. G. G. C.; Writing - Original Draft: Pinto, J. V. N. and Souza. P. J. O. P.; Writing - Review and Editing: Sousa, D. P., Nunes, H. G. G. C., Melo-Abreu, J. P. M., Souza, E. B. and Souza, P. J. O. P.; Funding Acquisition: Sousa, A. M. L. and Souza, P. J. O. P.; Supervision: Souza, P. J. O. P.

\section{DATA AVAILABILITY STATEMENT}

All data sets were generated or analyzed in the current study.

\section{FUNDING}

Conselho Nacional de Desenvolvimento Cientifico e Tecnológico

[https://doi.org/10.13039/501100003593]

Grant No. 483402/2012-5 and 311145/2013-2

\section{ACKNOWLEDGMENTS}

Not applicable. 


\section{REFERENCES}

Allen, R. G., Pereira, L. S., Raes, D. and Smith, M. (1998). Crop Evapotranspiration: Guidelines for computing crop water requirements [FAO Irrigation and drainage paper 56]. Rome: FAO.

Almeida, F. S., Mingotte, F. L. C., Lemos, L. B. and Santana, M. J. (2017). Agronomic performance of cowpea cultivars depending on sowing seasons in the cerrado biome. Revista Caatinga, 30, 361-369. https://doi.org/10.1590/1983-21252017v30n211rc

Andrade Júnior, A. S., Barros, A. H. C., Silva, C. O. and Freire Filho, F. R. (2007). Zoneamento de risco climático para a cultura do feijãocaupi no estado do Ceará. Revista Ciência Agronômica, 38, 109-117.

Andrade Júnior, A. S., Bastos, E. A. and Monteiro, J. E. B. A. (2018). Zoneamento agrícola de risco climático para o feijão-caupi em cultivo convencional e plantio direto no estado do Piauí [Documentos 253]. Teresina: Embrapa Meio-Norte.

Angelotti, F., Barbosa, L. G., Barros, J. R. A. and Santos, C. A. F. (2020). Cowpea development under different temperatures and carbon dioxide concentrations. Pesquisa Agropecuária Tropical, 50, e59377. https://doi.org/10.1590/1983-40632020v5059377

Auras, N. E. and Amâncio, C. O G. (2015). Cultivo de feijão-caupi em municípios dos estados do Norte, Nordeste e Centro-Oeste, conforme a área colhida e a produtividade [Documentos 300]. Seropédica: Embrapa Agrobiologia.

Berbel, J., Borrego-Marin, M. M., Exposito, A., Giannoccaro, G., Montilla-Lopez, N. M. and Roseta-Palma, C. (2019). Analysis of irrigation water tariffs and taxes in Europe. Water Policy, 21, 806-825. https://doi.org/10.2166/wp.2019.197

Carvalho, A. L., Menezes, R. S. C., Nóbrega, R. S., Pinto, A. S., Ometto, J. P. H. B., von Randow, C. and Giarolla, A. (2015). Impact of climate changes on potential sugarcane yield in Pernambuco, northeastern region of Brazil. Renewable Energy, 78, 26-34. https://doi. org/10.1016/j.renene.2014.12.023

Cavalcante Junior, E. G., Medeiros, J. F., Sobrinho, J. E., Figueiredo, V. B., Costa, J. P. N. and Santos, W. O. (2016). Development and water requirements of cowpea under climate change conditions in the Brazilian semi-arid region. Revista Brasileira de Engenharia Agrícola e Ambiental, 20, 783-788. https://doi.org/10.1590/1807-1929/agriambi.v20n9p783-788

Cirad. (2013). SARRA-H: Le bilan hydrique. Cirad. [Accessed Feb. 20, 2020]. Available at: https://sarra-h.teledetection.fr/SARRAH_BH.html [Conab] Companhia Nacional de Abastecimento. (2021). Acompanhamento da Safra Brasileira de Grãos: Safra 2020/21, $7^{\circ}$ levantamento. Brasília: Conab.

Cunha, D. A., Coelho, A. B., Féres, J. G. and Braga, M. J. (2014). Effects of climate change on irrigation adoption in Brazil. Acta Scientiarum Agronomy, 36, 1-9.

Daryanto, S., Wang, L. and Jacinthe, P.-A. (2017). Global synthesis of drought effects on cereal, legume, tuber and root crops production: A review. Agricultural Water Management, 179, 18-33. https://doi.org/10.1016/j.agwat.2016.04.022

Durojaye, H. A., Moukoumbi, Y. D., Dania, V. O., Boukar, O., Bandyopadhyay, R. and Ortega-Beltran, A. (2019). Evaluation of cowpea (Vigna unguiculate (L.) Walp.) landraces to bacterial blight caused by Xanthomonas axonopodis pv. vignicola. Crop protection, 116, 77-81. https://doi.org/10.1016/j.cropro.2018.10.013

Fan, X., Cao, X., Zhou, H., Hao, L., Dong, W., He, C., Xu, M., Wu, H., Wang, L., Chang, Z. and Zheng, Y. (2020). Carbon dioxide fertilization effect on plant growth under soil water stress associates with changes in stomatal traits, leaf photosynthesis, and foliar nitrogen of bell pepper (Capsicum annuum L.). Environmental and Experimental Botany, 179, 104203. https://doi.org/10.1016/j.envexpbot.2020.104203

Farias, V. D. S., Lima, M. J. A., Nunes, H. G. G. C., Sousa, D. P. and Souza, P. J. O. P. (2017). Water demand, crop coefficient and uncoupling factor of cowpea in the eastern Amazon. Revista Caatinga, 30, 190-200. https://doi.org/10.1590/1983-21252017v30n121rc

Ferreira, D. B. S., Souza, E. B., Moraes, B. C. and Meira Filho, L. G. (2015). Spatial and temporal variability of rainfall in Eastern Amazon during the rainy season. The Scientific World Journal, 1, 209783. https://doi.org/10.1155/2015/209783 
Freitas, R. M. O., Dombroski, J. L. D., Freitas, F. C. L., Nogueira, N. W. and Pinto, J. R. S. (2017). Physiological responses of cowpea under water stress and rewatering in no-tillage and conventional tillage systems. Revista Caatinga, 30, 559-567. https://doi. org/10.1590/1983-21252017v30n303rc

Gabarron-Galeote, M. A., Hannam, J. A., Mayr, T. and Jarvis, P.J. (2019). BEETSOIL: A decision support tool for forecasting the impact of soil conditions on sugar beet harvest. Soil and Tillage Research, 191, 131-141. https://doi.org/10.1016/j.still.2019.04.001

Gao, J., Han, X., Seneweera, S., LI, P., Zong, Y.-z, Dong, Q., Lin, E.-d. and Hao, X.-y. (2015). Leaf photosynthesis and yield components of mung bean under fully open-air elevated [CO2]. Journal of Integrative Agriculture, 14, 977-983. https://doi.org/10.1016/S2095-3119(14)60941-2

Gomes, W. B., Correia, F. W. S., Capistrano, V. B., Veiga, J. A. P., Vergasta, L. A., Chou, S. C., Lyra, A. A., Nobre, P. and Rocha, V. M. (2020). Water budget changes in the Amazon basin under RCP 8.5 and deforestation scenarios. Climate Research, 80, 105-120. https://doi.org/10.3354/cr01597

Harvey, C. A., Saborio Rodríguez, M., Martinez Rodríguez, M. R., Viguera, B., Chain Guadarrama, A., Vignola, R. and Alpizar, F. (2018). Climate change impacts and adaptation among smallholder farmers in Central America. Agriculture and Food Security, 7, 57. https:// doi.org/10.1186/s40066-018-0209-x

Hatfield, J. L. and Dold, C. (2019). Water-use efficiency: Advances and challenges in a changing climate. Frontiers in Plant Science, 10, 103. https://doi.org/10.3389/fpls.2019.00103

Kimiti, J. M. (2019). Cowpea (Vigna unguiculata) fast establishment enhances its potential for food security and shortterm rotations in semi-arid areas in a changing climate. International Journal of Science and Research, 8, 849-853.

Kumar, A., Nayak, A. K., Das, B. S., Panigrahi, N., Dasgupta, P., Mohanty, S., Kumar, U., Panneerselvam, P. and Pathak, H. (2019). Effects of water deficit stress on agronomic and physiological responses of rice and greenhouse gas emission from rice soil under elevated atmospheric $\mathrm{CO}_{2}$. Science of the Total Environment, 650, 2032-2050. https://doi.org/10.1016/j.scitotenv.2018.09.332

Lathuillière, M. J., Coe, M T., Castanho, A., Graesser, J. and Johnson, M. S. (2018). Evaluating water use for agricultural intensification in southern Amazonia using the water footprint sustainability assessment. Water, 10, 349. https://doi.org/10.3390/w10040349

Lima Filho, A. F., Coelho Filho, M. A. and Heinemann, A. B. (2013). Determinação de épocas de semeadura do feijão caupi no Reconcavo Baiano através do modelo CROPGRO. Revista Brasileira de Engenharia Agrícola e Ambiental, 17, 1294-1300. https://doi.org/10.1590/ S1415-43662013001200007

Mamalakis, A., Randerson, J. T., Yu, J.-Y., Pritchard, M. S., Magnusdottir, G., Smyth, P., Levine, P. A., Yu, S. and Foufoula-Georgiou, E. (2021). Zonally contrasting shifts of the tropical rain belt in response to climate change. Nature Climate Change, 11, 143-151. https://doi. org/10.1038/s41558-020-00963-x

Matoso, A. O., Soratto, R. P., Guarnieri, F., Costa, N. R., Abrahão, R. C. and Tirabassi, L. H. (2018). Sowing date effects on cowpea cultivars as a second crop in Southeastern Brazil. Agronomy Journal, 110, 1799-1812. https://doi.org/10.2134/agronj2018.01.0051

Molotoks A., Smith, P. and Dawson, T. P. (2021). Impacts of land use, population, and climate change on global food security. Food and Energy Security, 10, e261. https://doi.org/10.1002/fes3.261

Nascimento, S. P., Bastos, E. A., Araújo, E. C. E., Freire Filho, F. R. and Silva, E. M. (2011). Tolerância ao déficit hídrico em genótipos de feijão-caupi. Revista Brasileira de Engenharia Agrícola e Ambiental, 15, 853-860. https://doi.org/10.1590/S1415-43662011000800013

Nunes, H. G. G. C., Sousa, D. P.; Moura, V. B., Ferreira, D. P., Pinto, J. V. N., Vieira, I. C. O., Farias, V. D. S., Oliveira, E. C. and Souza, P. J. O. P. (2019). Performance of the AquaCrop model in the climate risk analysis and yield prediction of cowpea (Vigna unguiculata L. Walp). Australian Journal of Crop Science, 13, 1105-1112. https://doi.org/10.21475/ajcs.19.13.07.p1590

Pires, G. F., Abrahão, G. M., Brumatti, L. M., Oliveira, L. J. C., Costa, M. H., Liddicoat, S., Kato, E. and Ladle, R. J. (2016). Increased climate risk in Brazilian double cropping agriculture systems: Implications for land use in Northern Brazil. Agricultural and Forest Meteorology, 228-229, 286-298. https://doi.org/10.1016/j.agrformet.2016.07.005 
Pokhrel, Y., Felfelani, F., Satoh, Y., Boulange, J., Burek, P., Gädeke, A., Gerten, D., Gosling, S. N., Grillakis, M., Gudmundsson, L., Hanasaki, N., Kim, H., Koutroulis, A., Liu, J., Papadimitriou, L., Schewe, J., Schmied, H. M., Stacke, T., Telteu, C.-E., Thiery, W., Veldkamp, T., Zhao, F. and Wada, Y. (2021). Global terrestrial water storage and drought severity under climate change. Nature Climate Change, 11, $226-233$. https://doi.org/10.1038/s41558-020-00972-w

Rocha, V. M., Correia, F. W. S. and Gomes, W. B. (2019). Avaliação dos impactos da mudança do clima na precipitação da Amazônia utilizando o modelo RCP 8.5 Eta-HadGEM2-ES. Revista Brasileira de Geografia Física, 12, 2051-2065. https://doi.org/10.26848/rbgf. v12.6.p2051-2065

Sánchez-Navarro, V., Zornoza, R., Fáz, A. and Fernadéz, J. A. (2019). Does the use of cowpea in rotation with a vegetable crop improve soil quality and crop yield and quality? A field study in SE Spain. European Journal of Agronomy, 107, 10-17. https://doi.org/10.1016/j. eja.2019.03.007

Seifert, C. A. and Lobell, D. B. (2015). Response of double cropping suitability to climate change in the United States. Environmental Research Letters, 10, 024002. https://doi.org/10.1088/1748-9326/10/2/024002

Silva, V. P. R., Campos, J. H. B. C., Silva, M. T. and Silva, P. V. (2010). Impact of global warming on cowpea bean cultivation in northeastern Brazil. Agricultural Water Management, 97, 1760 1768. https://doi.org/10.1016/j.agwat.2010.06.006

Solaun, K. and Cerdá, E. (2020). Impacts of climate change on wind energy power: Four wind farms in Spain. Renewable Energy, 145, 1306-1316. https://doi.org/10.1016/j.renene.2019.06.129

Souza, E. B., Carmo, A. M. C., Moraes, B. C., Nacif, A., Ferreira, D. B. S., Rocha, E. J. P. and Souza, P. J. O. P. (2016). Sazonalidade da precipitação sobre a Amazônia legal brasileira: Clima atual e projeções futuras usando o modelo RegCM4. Revista Brasileira de Climatologia, 18, 293-306. https://doi.org/10.5380/abclima.v18i0.43711

Souza, E. B., Ferreira, D., B. S., Guimarães, J. T. F., Franco, V. S., Azevedo, F. T. M. and Souza, P. J. O. P. (2017). Padrões climatológicos e tendências da precipitação nos regimes chuvoso e seco da Amazônia Oriental. Revista Brasileira de Climatologia, 21, 81-93. https:// doi.org/10.5380/abclima.v21i0.41232

Souza, P. J. O. P., Ramos, T. F., Fiel, L. C. S., Farias, V. D. S., Sousa, D. P. and Nunes, H. G. G. C. (2019). Yield and water use efficiency of cowpea under water deficit. Revista Brasileira de Engenharia Agrícola e Ambiental, 23, 119-125. https://doi.org/10.1590/1807-1929/ agriambi.v23n2p119-125

Souza, P. J. O. P., Farias, V. D. S., Pinto, J. V. N., Nunes, H. G. G. C., Souza, E. B. and Fraisse, C. W. (2020). Yield gap in cowpea plants as function of water deficits during reproductive stage. Revista Brasileira de Engenharia Agrícola e Ambiental, 24, 372-378. https://doi. org/10.1590/1807-1929/agriambi.v24n6p372-378

Ueyama, M., Ichii, K., Kobayashi, H., Kumagai, T., Beringer, J., Merbold, L., Euskirchen, L., Hirano, T., Marchesini, L. B., Baldocchi, D., Saitoh, T. M., Mizoguchi, Y., Ono, K., Kim, J., Varlagin, A., Kang, M., Shimizu, T., Kosugi, Y., Bret-Harte, M. S., Machimura, T., Matsuura, Y., Ohta, T., Takagi, K., Takanashi, S. and Yasuda, Y. (2020). Inferring CO2 fertilization effect based on global monitoring land-atmosphere exchange with a theoretical model. Environmental Research Letters, 15, 084009. https://doi.org/10.1088/1748-9326/ab79e5

Vicente-Serrano, S. M., Nieto, R., Gimeno, L., Azorin-Molina, C., Drumond, A., El Kenawy, A., Dominguez-Castro, F., Tomas-Burguera, M. and Peña-Gallardo, M. (2018). Recent changes of relative humidity: Regional connections with land and ocean processes. Earth Syst Dynamics, 9, 915-937. https://doi.org/10.5194/esd-9-915-2018

Zilli, M., Scarabello, M., Soterroni, A. C., Valin, H., Mosnier, A., Leclère, D., Havlík, P., Kraxner, F., Lopes, M. A. and Ramos, F. M. (2020). The impact of climate change on Brazil's agriculture. Science of The Total Environment, 740, 139384. https://doi.org/10.1016/j. scitotenv.2020.139384 